\title{
Implementasi Pembiayaan Manindo Grameen Syariah dengan Akad Murabahah pada Koperasi Mitra Manindo Cabang Panyabungan
}

\author{
Jureid \\ Sekola Tinggi Agama Islam Negeri Mandailing Natal \\ Email:jureid@stain-madina.ac.id
}

Abstract : Manindo Grameen Syariah (MGS) product is a non collateral financing product for Koperasi Mitra Manindo customers. It is a solution for the poor in obtaining business financing. Koperasi Mitra Manindo adopts the Grameen Bank system and combine it with a murabahah agreement to make it easier for poor women to obtain Startup Capital. This study used a qualitative approach with descriptive analysis by describing the actual information obtained from the respondents. Data collection techniques are through documentation, observation and interview with interviewess in order to produce in-depth and objective data. The results of this study conclude that in implementing Murabahah financing, Koperasi Mitra Manindo does not provide goods as Murabahah objects but provides money without using the wakalah contract as a complement to the contract. In this case, Koperasi uses a mudharabah financing scheme with a murabahah contract but it still causes damage to the contract due to the absence of object objects. Manindo Grameen Syariah financing with a murabahah contract carried out by the Manindo Mitra Cooperative is not in accordance with the murabahah principle, particularly about the object of goods (mabi '), Koperasi Mitra Manindo is supposed to act as a seller does not have goods to be traded but only provides money as business capital for its members.

Keywords : Cooperative, Murabahah, contract, Mitra Manindo

Abstrak : Produk Manindo Grameen Syariah (MGS) merupakan produk pembiayaan tanpa pembebanan agunan terhadap nasabah oleh Koperasi Mitra Manindo sebagai salah satu solusi bagi masyarakat miskin dalam mendapatkan pembiayaan usaha, Koperasi Mitra Manindo mengadopsi sistem Grameen Bank dan mengkolaborasikannya dengan akad murabahah untuk mempermudah kaum perempuan miskin dalam mendapatkan modal usaha. Penelitian ini menggunakan pendekatan kualitatif dengan analisis deskriptif yaitu dengan cara memaparkan informasi aktual yang diperoleh dari responden. Teknik pengumpulan data melalui dokumentasi, observasi dan wawancara terhadap narasumber agar menghasilkan data yang mendalam dan objektif. Hasil penelitian ini menyimpulkan dalam melaksanakan pembiayaan Murabahah Koperasi Mitra Manindo tidak menyediakan barang sebagai objek Murabahah melainkan menyediakan uang tanpa menggunakan akad wakalah sebagai pelengkap akad, dalam hal ini koperasi menggunakan skema pembiayaan mudharabah dengan akad murabahah tetapi tetap dengan skema Mudharabah hal ini menyebabkan rusaknya rukun akad murabahah karena ketiadaan objek barang. Pembiayaan Manindo Grameen Syariah dengan akad murabahah yang dilaksanakan oleh Koperasi Mitra Manindo belum sesuai dengan rukun murabahah yaitu objek barang (mabi'), dikarenakan pihak koperasi yang seharusnya bertindak sebagai penjualan tidak memiliki barang untuk diperjualbelikan melainkan hanya memberikan uang sebagai modal usaha bagi anggotanya

Kata Kunci : : Koperasi, Murabahah, akad, Mitra Manindo

\section{A. Pendahuluan}

Kemiskinan (poverty) merupakan salah satu masalah serius bagi setiap negara, di antara sekian masalah lainnya berdasarkan ekonomi. Kemiskinan secara ekonomi terjadi karena kekurangan sumber daya atau modal untuk meningkatkan dan memajukan kesejahteraan. ${ }^{1}$ Kekurangan modal dalam upaya mendirikan suatu perusahaan atau usaha untuk menopang

\footnotetext{
${ }^{1}$ Ahmad Fauzan Mubarok, "Tinjauan Hukum Islam Terhadap Program Pengentasan Kemiskinan Oleh Grameen Bank,” ISTI'DAL; Jurnal Studi Hukum Islam 4, no. 2 (2017): 105-119, https://ejournal.unisnu.ac.id/JSHI/article/view/775/1040.
} 
perekonomian masyarakat sebenarnya bisa diatasi dengan adanya pemberian kredit yang diberikan lembaga bank ataupun nonbank.

Grameen Bank atau Bank untuk golongan miskin adalah suatu metode Perekonomian mikro yang digagas oleh seorang Profesor dari Universitas Chittagong Banglades yang bernama Muhammad Yunus. Grameen Bank berawal dari Unit Usaha Kredit di desa Jobra yang memberikan pembiayaan modal usaha kepada masyarakat miskin tanpa agunan, karena beliau yakin yang dibutuhkan masyarakat miskin adalah modal untuk memulai usaha. ${ }^{2}$

Keberhasilan Grameen Bank yang dipelopori oleh Muhammad Yunus dalam mengentaskan kemiskinan di Banglades mengantarkan dirinya dan Gramen Bank menjadi peraih hadiah Nobel Perdamaian yang dianugrahkan oleh Komite Nobel Norwegia pada tanggal 13 Oktober $2006 .^{3}$

Indonesia sebagai salah satu negara berkembang juga tertarik untuk mengadopsi sistem grameen bank dalam lembaga keuangannya. Objek utama grameen bank adalah masyarakat miskin terutama perempuan dengan tujuan memerdekakan mereka secara finansial. Grameen bank memberikan kredit mikro kepada anggotanya dengan berbagai programnya. ${ }^{4}$ Rentang jumlah atau besaran kredit yang diberikan oleh grameen bank bervariasi sesuai dengan jenis atau program usaha yang diajukan. Sebagai jaminan kredit untuk tetap aman dan tidak diselewengkan, maka grameen bank menerapkan internal control system antar anggota dalam satu grup kredit. ${ }^{5}$

Kredit Mikro atau disebut pembiayaan yang diberikan oleh grameen bank adalah pembiayaan yang sifatnya untuk modal kerja jangka pendek, sehingga para kaum perempuan harus menyiapkan portofolio usaha sebelum mengambil pembiayaan. Pembiayaan modal kerja sebagaimana diatur dalam perbankan syariah harus berdasarkan prinsip-prinsip syariah. Jangka waktu yang dibutuhkan maksimum satu tahun dan dapat diperpanjang bila diperlukan. ${ }^{6}$

Koperasi Mitra Manindo adalah salah satu Lembaga Keuangan Mikro yang mengadaptasi pola sistem Grameen Bank yang ada di Banglades, Koperasi Mitra Manindo adalah koperasi jasa keuangan syariah yang memberikan pinjaman kepada anggota atau calon anggotanya tanpa agunan khususnya bagi kaum perempuan miskin di Indonesia, atau yang lebih dikenal dengan sebutan "kredit mikro" atau " micro finance" yang sesuai dengan prinsip syariah.

Koperasi Mitra Manindo (KMM) berdiri berdasarkan Surat Keputusan Menteri Negara Koperasi dan Usaha Kecil dan Menengah Nomor 843/BH/MENEG.I/V/2009 Tanggal 14 Mei 2009 tentang Pengesahan Akta Pendirian Koperasi Mitra Manindo. Koperasi Mitra Manindo berkantor pusat di Jalan Rambutan Nomor 22, Rt, 006/03, Kelurahan Kalisari, Kecamatan Pasar Rebo, Jakarta Timur 13790, Sejak tanggal 19 Mei 2009 Koperasi Mitra Manindo telah membuka kantor perwakilan dan cabang di Panyabungan yang beralamat di Jalan Pahlawan Nomor 3, Kelurahan Panyabungan II, Kecamatan Panyabungan, Kabupaten Mandailing Natal.

${ }^{2}$ Muhammad Yunus and Alan Jolis, Bank Kaum Miskin (Serpong: Marjin Kiri, 2013).

${ }^{3}$ Ibid.

${ }^{4}$ Tanbir Ahmed Chowdhury and Sehel Somani, "Performance Evaluation and Impact of Grameen Bank on Social Development and Women Empowerment in Bangladesh," International Journal of Social and Administrative Sciences 5, no. 1 (2020): 54-73.

${ }^{5}$ Mubarok, "Tinjauan Hukum Islam Terhadap Program Pengentasan Kemiskinan Oleh Grameen Bank."

${ }^{6}$ Khairiah Elwardah, "Penyelesaian Pembiayaan Bermasalah Dalam Produk Pembiayaan Murabahah (Studi Pada Pt. Bprs Muamalat Harkat Sukaraja)," Jurnal BAABU AL-ILMI: Ekonomi dan Perbankan Syariah 4, no. 1 (2019): 75. 
Lembaga Keuangan Mikro Syariah adalah lembaga keuangan yang usaha pokoknya memberikan pembiayaan (penyaluran pinjaman) dan jasa lainnya dalam sebuah lalu lintas pembayaran yang operasionalnya disesuaikan dengan prinsip-prinsip syariah. ${ }^{7}$ Koperasi Mitra Manindo adalah salah satu lembaga keuangan yang mempunyai kegiatan menarik dan menyalurkan uang kepada masyarakat melalui produk usaha koperasi dengan berpedoman pada prinsip-prinsip syariah.

Sebagai salah satu Lembaga Keuangan Mikro Syariah, Koperasi Mitra Manindo dalam pelaksanaannya mengedepankan prinsip bagi hasil sebagai sebuah instrument keuangan pengganti sistem bunga atau riba, hubungan Lembaga Keuangan Mikro Syariah dengan anggotanya (nasabah) adalah sebagai mitra bagi investor yang akan memantau perkembangan usaha para anggota. Koperasi Mitra Manindo juga dalam pelaksanaannya memantau perkembangan usaha anggotanya melalui pertemuan rutin yang dilaksanakan setiap pekannya sehingga mengakibatkan kedua belah pihak yang bertransaksi akan saling memperhatikan kemajuan maupun kemunduran usaha yang dijalankannya. ${ }^{8}$

Salah satu akad pembiayaan yang populer dalam Lembaga Keuangan Syariah di masyarakat adalah akad murabahah, yang mana akad tersebut merupakan suatu akad pembiayaan pembelian barang yang dilakukan oleh lembaga keuangan Syariah dalam membantu masyarakat untuk memperoleh barang yang diinginkan dengan cara membiayai pembelian barang dengan menyebutkan harga pokok dari produk dan keuntungan yang disepakati kedua belah pihak. ${ }^{9}$ Akad ini dapat disebut sebagai natural certainty cotracts, yang ditentukan berapa berapa keuntungan yang ingin diperoleh (required rate of profit). ${ }^{10}$

Dalam Fatwa Dewan Syariah Nasional No:04/DSN-MUI/IV/2000 yang menjelaskan bahwa "akad murabahah merupakan akad jual beli barang yang mana barang tersebut merupakan barang yang tidak diharamkan menurut syariat Islam serta bank ataupun lembaga keuangan non bank harus menjelaskan harga barang sebelumnya plus keuntungannya". Akad murabahah menegaskan harga jual dan beli kepada pembeli sehingga pembeli harus membayar lebih dari harga tersebut untuk mendapatkan keuntungan. ${ }^{11}$ Harga pokok dan tambahan untuk keuntungan harus disampaikan secara transparan termasuk biayabiaya proses sebelum terjadi akad. ${ }^{12}$ Hal ini dilakukan untuk memenuhi syarat disebut akad murabahah.

Pembiayaan dengan akad murabahah yang ada di Koperasi Mitra Manindo Cabang Panyabungan berbeda dengan pengertian murabahah yang ada dalam Fatwa Dewan Syariah

${ }^{7}$ Lokot Zein Nasution, “Analisis Manajemen Risiko Pembiayaan Mikro Syariah Berbasis Karakteristik Masyarakat (Studi Pada Koperasi Mitra Manindo, Kabupaten Mandailing Natal, Sumatera Utara)," Jurnal Islaic $\begin{array}{lllll}\text { Circle } & 1, & 1 & \text { (2020): } & 1-26 \text {, }\end{array}$ https://doi.org/10.1016/j.tmaid.2020.101607\%0Ahttps://doi.org/10.1016/j.ijsu.2020.02.034\%0Ahttps://onlinelibr ary.wiley.com/doi/abs/10.1111/cjag.12228\%0Ahttps://doi.org/10.1016/j.ssci.2020.104773\%0Ahttps://doi.org/10. 1016/j.jinf.2020.04.011\%0Ahttps://doi.o.

8 Anni Sopiah, "Analisis Peranan Koperasi Mitra Manindo Siabu Dalam Meningkatkan Pendapatan Anggota Koperasi (Studi Kasus Di Desa Simaninggir)” (Institut Agama ISlam Negeri (IAIN) Padangsidempuan, 2019).

${ }^{9}$ Adiwarman Karim, Bank Islam : Analisis Fiqih Dan Keuangan (Jakarta: Raja Grafindo, 2006).

${ }^{10}$ Esti Alfiah, "Murabahah Contract With Delaying of Handover Object For Financing Mulia's Program (Case Studies at Pegadaian Syariah of Bengkulu)," Jurnal BAABU AL-ILMI: Ekonomi dan Perbankan Syariah 3, no. 1 (2019).

${ }^{11}$ Ibid.

${ }^{12}$ Baidhowi, "Rekonstruksi Akad Murabahah (Studi Akad Murabahah Di BMT SM NU Pekalongan)," YUDISIA: Jurnal Pemikiran Hukum dan Hukum Islam 8, no. 2 (2017): 221-239. 
Nasional, dalam praktiknya Koperasi Mitra Manindo memberikan pembiayaan dengan akad murabahah tanpa menjelaskan jenis maupun harga barang yang akan dibiayai secara rinci.

Koperasi Mitra Manindo mensyaratkan kepada anggota dan calon anggota untuk mempunyai jenis usaha, Koperasi Manindo memberikan pembiayaan dengan akad murabahah kepada anggota dan calon anggotanya dalam bentuk uang yang dibutuhkannya diukur berdasarkan kemampuan usaha yang dimilikinya. ${ }^{13}$ Dalam pengambilan keuntungan, pembiayan dengan akad murabahah yang diberikan Koperasi Mitra Manindo Cabang Panyabungan ditentukan diawal akad berdasarkan persentase banyaknya jumlah uang yang dipinjamkan bukan berdasarkan harga barang yang dibiayai, padahal seyogyanya akad murabahah adalah jual beli barang yang menyebutkan harga pokok barang plus keuntungan.

Sepanjang pengamatan yang dilakukan oleh penulis Koperasi Manindo Cabang Panyabungan tidak menyediakan pembiayaan yang diberikan dalam bentuk barang, Koperasi Mitra Manindo Cabang Panyabungan mengganti barang tersebut dengan uang tunai, dengan alasan memberi kebebasan pada anggota untuk menggunakan uang pembiayaan sesuai dengan apa yang anggota atau calon anggota butuhkan sesuai dengan jenis usaha mereka.

\section{B. Metode Penelitian}

Dalam penelitian ini, penulis meneliti dengan menggunakan jenis penelitian kualitatif deskriptif, yaitu menggambarkan fakta berdasarkan data-data lapangan sebagai sumber data utama, seperti hasil wawancara dan observasi. ${ }^{14}$ Sumber data yang penulis gunakan dalam penelitian ini adalah data primer dan sekunder. Data primer yaitu data yang diperoleh secara langsung dari sumber pertama yang berkaitan dengan masalah yang akan dibahas dari sumbernya langsung. Sumber data yang diperoleh langsung dari lapangan secara langsung ialah wawancara kepada para pengelola Koperasi Mitra Manindo Cabang Panyabungan Kabupaten Mandailing Natal Provinsi Sumatera Utara yaitu Manager Operasional dan petugas lapang. Data Sekunder yaitu sumber yang dapat memberikan informasi atau data tambahan yang dapat memperkuat data pokok, baik berupa manusia atau benda (majalah, buku, koran, brosur, dokumen-dokumen resmi Koperasi Mitra Manindo cabang Panyabungan, dan lain lain). Dalam penelitian ini yang menjadi sumber data sekunder untuk penulis adalah buku-buku pendukung tentang koperasi, Grameen, Murabahah, dan Fatwa Dewan Syariah Nasional yang berkaitan dengan ini.

\section{Hasil dan Pembahasan}

\section{Implementasi Pembiayaan Manindo Grameen Syariah dengan Akad Murabahah pada Koperasi Mitra Manindo Cabang Panyabungan}

Produk Manindo Grameen Syariah adalah pembiayaan murabahah yang ditawarkan oleh Koperasi Mitra Manindo Cabang Panyabungan yang merupakan produk pembiayaan produktif dengan akad Murabahah. Penyaluran dana atau pembiayaan produktif atau Pembiayaan Murabahah yaitu pembiayaan dengan prinsip jual beli barang pada harga pokok dengan tambahan bagi hasil yang disepakati, dimana pihak koperasi selaku penjual dan anggota selaku pembeli, pembayaran dapat dilakukan secara angsuran sesuai dengan kesepakatan bersama.

Pembiayaan ini cocok untuk anggota yang membutuhkan tambahan aset namun kekurangan dana untuk melunasinya secara tunai. Transaksi pembiayaan murabahah yang

\footnotetext{
${ }^{13}$ Hoiriah Lubis, Wawancara Pribadi, Sabtu,09 Januari 2021.

${ }^{14}$ Farida Nugrahani, Metode Penelitian Kualitatif (Jakarta: Library Stiba, 2014).
} 
dilakukan di Koperasi Mitra Manindo Cabang Panyabungan, digunakan untuk pembiayaan yang ditujukan kepada anggota untuk tambahan modal usaha, seperti pembiayaan untuk menambah kapasitas serta produktifitas usaha.Sehingga pembiayaan murabahah juga disebut pembiayaan produktif. ${ }^{15}$

Akad murabahah yang ada dalam Koperasi Mitra Manindo Cabang Panyabungan merupakan suatu usaha dalam rangka melakukan pendekatan kepada masyarakat awam yang belum mengerti berbagai macam transaksi dalam Islam. Bagi masyarakat yang terpenting adalah bagaimana mereka dapat meminjam uang dengan mudah dan cepat.

Kegiatan utama dari sebuah lembaga keuangan adalah penyaluran dana dalam pembiayaan, salah satunya adalah penyaluran dana murabahah untuk masyarakat, penyaluran dana ini dilakukan guna membantu masyarakat, adapun salah satu cara untuk menyaluran dana kepada masyarakat adalah dengan menyediakan pembiayaan murabahah.

Pelaksanan praktek dalam pembiayaan murabahah yang dikelola oleh Koperasi Mitra Manindo Cabang Panyabungan merupakan produk dengan prinsip kerja sama dengan menggunakan akad perjanjian. Dalam prakteknya, prinsip pembiayaan murabahah dilakukan oleh dua orang atau pihak, dimana pihak pertama sebagai pemilik modal atau (shahibul maal) dan pihak kedua pengelola modal atau anggota, yang disebut sebagai (mudharib). Koperasi Mitra Manindo dalam perjanjian akad menggunakan Istilah Koperasi dan anggota koperasi.

Awal mulanya dalam proses penandatanganan perjanjian murabahah pihak Koperasi Mitra Manindo menjelaskan secara terperinci biaya-biaya apa saja yang dikeluarkan oleh koperasi, namum dalam praktiknya anggota tidak menginginkan proses yang bertele-tele dan merepotkan, anggota selaku pengelola modal menginginkan proses yang cepat. Berdasarkan kesepakatan bersama, pihak koperasi tidak menyediakan barang melainkan hanya menyediakan uang yang diperlukan oleh Anggota koperasi sesuai dengan rincian permohonan yang di ajukan untuk pembiayaan modal usaha, tanpa adanya tambahan surat keterangan akad wakalah yang berisi tentang penggantian barang dengan uang senilai pembiayaan yang diberikan. ${ }^{16}$

Pembiayaan Manindo Grameen Syariah di Koperasi Mitra Manindo Cabang Panyabungan merupakan Implementasi pola grameen bank yang diadaptasi menjadi Pola Simpan Pinjam Metode Kumpulan (PSPMK), sesuai dengan pola grameen bank, PSPMK juga mengadaptasi metode yang sama, dengan menyasar kalangan perempuan pra-sejahtera, dengan membuat kumpulan yang berisikan lima orang anggota atau calon anggota, dan pada tingkat selanjutnya ada yang dinamakan dengan poken, poken berisikan minimum dua kumpulan dan maksimum delapan kumpulan. sehingga seluruh kegiatan pembiayaan dan simpanan terpusat menjadi satu tempat yang memudahkan petugas untuk collect dana dari anggota.

Koperasi Mitra Manindo Cabang Panyabungan dalam hal ini tidaklah sebagai penjual tetapi sebagai pihak yang memberi pebiayaan kepada anggota/calon anggotanya, dalam pembelian barang, anggota/calon anggota melakukannya setelah dana cair, tanpa adanya laporan kembali dari pihak anggota ataupun Koperasi menayakan mengenai rincian barang yang telah dibeli.

Mekanisme akad pembiayaan murabahah di Koperasi Mitra Manindo Cabang Panyabungan pada awalnya adalah penentuan akad. Tujuannya adalah agar pihak Koperasi

${ }^{15}$ Hoiriah Lubis, Wawancara Pribadi,Sabtu, 09 Januari 2021
${ }^{16}$ Hoiriah Lubis, Wawancara Pribadi,Sabtu, 09 Januari 2021

Jurnal Baabu Al-ilmiVolume 6 No. 1 AprilTahun 2021 | 19 
mengetahui maksud dari anggota/calon anggota mengajukan pembiayaan di koperasi untuk keperluan apa, apakah untuk keperluan konsumtif atau produktif.

Pihak koperasi dalam praktiknya untuk dapat menyalurkan pembiayaan Manindo Grameen Syariah melihat kelengkapan syarat yang telah dilengkapi oleh calon anggota. Koperasi Mitra Manindo Cabang Panyabungan menargetkan para pedagang kecil, home industry, pengrajin serta unit lain usaha yang produktif untuk menjadi anggota dalam pembiayaan Manindo Grameen Syariah oleh karena itu pihak koperasi juga akan melihat latar belakang dari calon anggota mulai dari keahlian serta pengalaman kerja. Hal ini dilakukan agar para calon anggota benar- benar dapat mengembangkan amanah dalam hal pinjaman pembiayaan untuk usaha yang dijalaninya. ${ }^{17}$ Jika calon anggota sudah melengkapi prosedur dan syarat yang telah ditentukan oleh pihak koperasi akan melakukan uji kelayakan kepada anggota/calon anggota setelah anggota/calon anggota dianggap layak untuk diberikan pembiayaan, maka pihak koperasi langsung mengkonfirmasi kepada anggota tersebut untuk dapat langsung melakukan akad atau perjanjian. ${ }^{18}$

Sebaliknya, bagi para calon anggota yang pengajuan pembiayaannya menjadi prioritas kedua juga akan dikonfirmasi untuk selanjutnya diberi pembekalan dan arahan dari pihak koperasi untuk mempersiapkan skill atau kemampuan dalam hal usaha yang ia jalankan, karena pihak koperasi akan kembali menerima pengajuan pembiayaan bagi calon anggota yang sebelumnya menjadi prioritas kedua setelah semua calon anggota yang layak menjadi anggota.

Pembiayaan akan dicairkan setelah disetujui oleh Manager Operational dan Ketua Koperasi Mitra Manindo seminggu setelah petugas lapang menerima pengajuan pembiayaan dari anggota/calon anggota. Setelah pembiayaan cair, pihak koperasi akan menyalurkannya secara langsung tanpa perantara pihak lain, anggota wajib membayar simpanan pokok, simpanan wajib, dan simpanan LWK. Sipanan pokok dibayar sebesar Rp 100.000 dan bisa di anggsur selama menjadi anggota, simpanan wajib Rp. 1.000 per minggu, simpanan LWK sebesar Rp. 1.000. Dalam penyaluran ini, pihak koperasi tidak lagi memberikan syarat tambahan kepada anggota, karena syarat awal saat pengajuan pembiayaan dinilai sudah cukup sebagai pegangan bagi Koperasi Mitra Manindo.

Sejauh ini anggota yang melakukan pembiayan dengan produk Manindo Grameen Syariah adalah sebanyak 2.092 (dua ribu sembilan puluh dua) anggota dengan 156 (seratus lima puluh) poken, yang mana dalam satu poken terdiri dari minimal dua dan maksimum delapan kumpulan, dan satu kumpulan terdiri dari lima orang anggota.minimal pinjaman sebesar Rp. 100.000 sampai dengan Rp.6.000.000 untuk setiap anggota.

a. Penyaluran pembiayaan untuk calon anggota baru adalah minimum RP 100.000 s.d Rp. 2.000.000 dengan jangka waktu cicilan maksimum25 Minggu, Sedangkan untuk pembiayaan kedua anggota akan diberikan pembiayaan sebesar Rp. 3.000 .000 dengan Jangka waktu cicilan selama 50 minggu (1 tahun) dengan ketentuan pada pembiayaan sebelumnya anggota tidak mempunyai tunggakan setelah mendapat persetujuan dari MO dan Ketua KMM. Untuk tahap pembiayaan ketiga dan seterusnya maka pembiayaan akan di berikan kepada anggota dengan besaran pembiayaan mualai dari Rp. 4.000 .000 s.d

\footnotetext{
${ }^{17}$ Hoiriah Lubis, Wawancara Pribadi,Sabtu, 09 Januari 2021

${ }^{18}$ Manindo, "Legalitas Kelembagaan", Standar Operasional dan Prosedur Mitra Manindo Pola Syariah, 2019, h. 33-35
} 
maksimal Rp. 6.000.000 secara bertahap untuk setiap tahapan pengajuan yang dilakukan oleh anggota koperasi.

\section{Skema Pembiayaan Manindo Grameen Syariah}

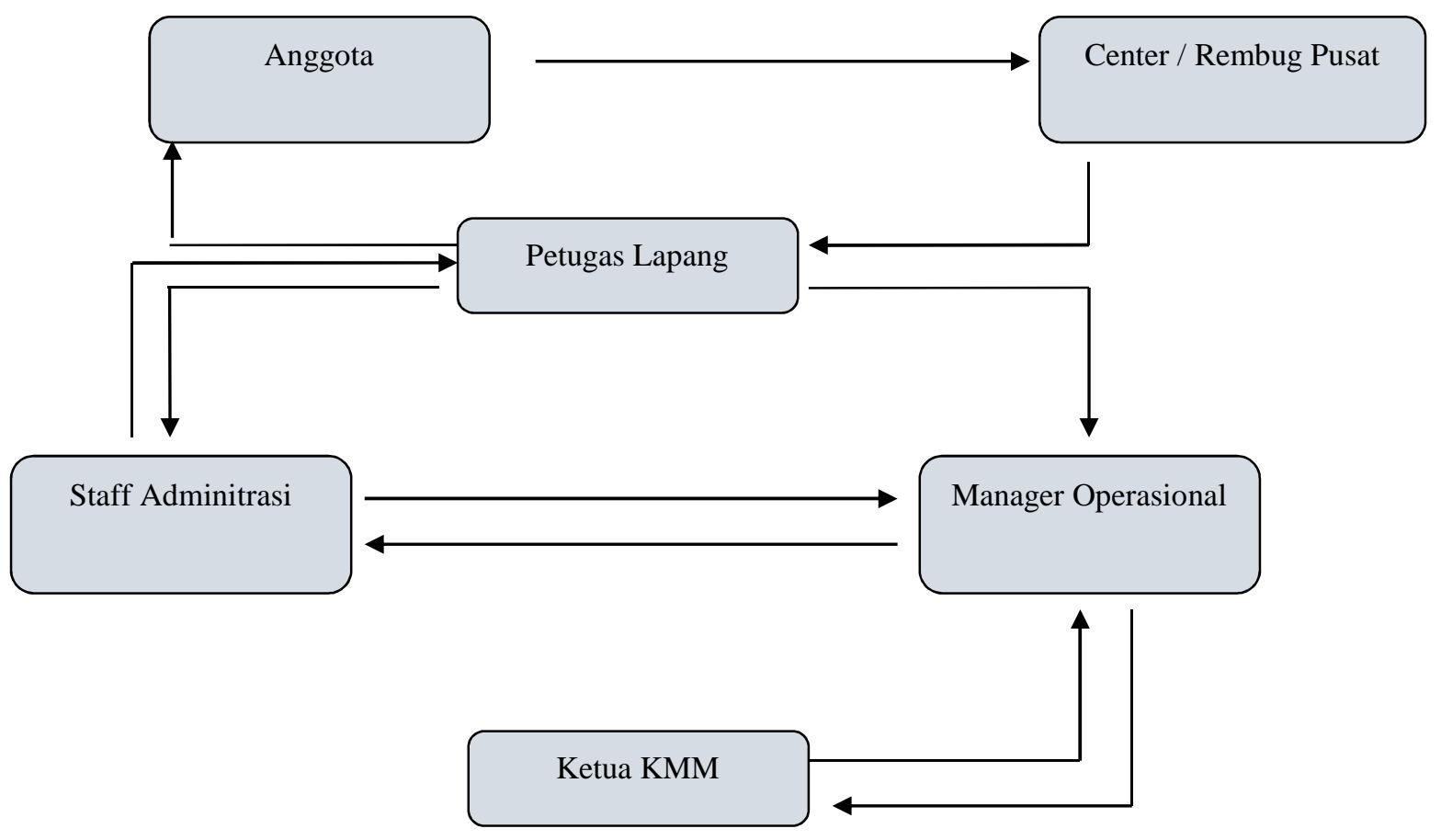

b. Calon penerima pembiayaan terdiri dari ${ }^{19}$ kaum perempuan, mendapat persetujuan dari suami jika status menikah, dan dari orang tua atau saudara kandung jika masih lajang. Selanjutnya, membentuk kelompok dan mengikuti atau lulus LWK.

c. Calon penerima pembiayaan harus memiliki usaha Produktif milik sendiri.

d. Calon penerima pembiayaan harus memiliki tempat tinggal tetap.

e. Dokumen yang harus dilengkapi adalah foto copy KTP, foto copy KK dan Foto copy KTP penanggung jawab.

f. Apabila dokumen lengkap, anggota/calon anggota mengajukan permohonan pembiayaan kepada petugas lapang, selanjutnya petugas lapang akan meminta persetujuan dari Manager Operational dan juga Ketua KMM. Seminggu stelah pengajuan pembiayaan petugas lapang akan mencairkan pembiayaan setelah persetujuan dari MO dan Ketua KMM didepan ketua dan anggota kumpulan yang akan menjadi saksi dalam hal tersebut.

g. Pencairan pembiayaan akan ditunda apabila terdapat anggota yang menunggak angsuran pembiayaan, pencairan akan dilaksanakan setelah tungkan di bayarkan baik itu langsung oleh penunggak atau tanggung jawab kelompok.

h. Bagi anggota koperasi yang tidak memiliki kemampuan bayar selama 3 (tiga) minggu berturut-turut akan menjadi tanggung jawab bersama dalam kumpulan.

i. Pemberian penundaan waktu (resecheduling), dilakukan dengan cara memperpanjang masa cicilan dengan tidak menambah margin.

j. Apabila anggota tidak memiliki kemampuan bayar, dimungkinkan akan ada kebijakan dari pihak Koperasi Mitra Manindo untuk mengurangi/menghapus margin sehingga anggota cukup membayar pokoknya saja.

\footnotetext{
${ }^{19}$ Fahrur Rozi, Wawancara Pribadi, Selasa, 12 Januari 2021
} 
k. Anggota yang melakukan pelunasan dipercepat dibolehkan untuk diberi potongan, berupa pengurangan margin.

1. Pada proses analisis, koperasi harus meminta anggota untuk merincikan apa saja penggunaan dana apabila dicairkan,, anggota harus merincikan apa saja yang akan dibeli termasuk biaya-biaya yang timbul. Memastikan jumlah sesuai dengan jumlah permohonan pembiayaan yang diajukan, Koperasi Mitra Manindo memberi penjelasan kepada calon penerima pembiayaan bahwa pembelian akan dilakukan oleh anggota sendiri dan pihak koperasi memberikan Sejumlah uang yang telah di rincikan oleh anggota/calon anggota koperasi.

m. Koperasi harus memperoleh keterangan tentang prospek usaha, yaitu apabila anggota menerima pembiayaan, maka anggota harus mampu menjelaskan kemungkinan perolehan pendapatan yang akan meningkat.

n. Penetapan margin dalam menentukan besarnya margin dalam praktek di Koperasi Mitra Manindo Cabang Panyabungan tidak dari harga barang pokok ditambah keuntungan melainkan sudah adanya penentuan bagi hasil dalam pembiayaan murabahah ini yang sudah ditetapkan pada awal perjanjian dari besarnya uang yang di pinjam bukan dari harga barang yang sesungguhnya. Besar bagi hasil ditentukan oleh Koperasi Mitra Manindo Cabang Panyabungan yaitu 2\% setiap bulannya sudah ditetapkan oleh Koperasi dikalikan dari uang yang dipinjam, dan tergantung dengan lamanya waktu Bagi hasil/nisbah merupakan keuntungan bagi Koperasi yang ditentukan pada awal terjadi kesepakatan (akad). Untuk anggota sudah ditetapkan 2\% per bulan hal ini diberlakukan bagi anggota baru dan anggota yang sudah melakukan akad pembiayaan sebelumnya.Dewan Pengawas Syari'ah mengeluarkan, mengizinkan produk-produk di mitra manindo panyabungan tidak hanya sekedar yang biasa-biasa saja, tetapi aturan yang dilaksanakan dimana menyangkut pelayanan-pelayanan, produk yang dikelola Koperasi, apalagi mengenai bagi hasil yang dikeluarkan sesuai aturan hukum syari'ah, memang kajian benar-benar syari'ah, apalagi mengenai bagi hasil telah ditentukan sesuai syari'ah. Dalam mengenai penentuan bagi hasil dalam pembiayaan murabahah $2 \%$ perbulan, penentuan ini ditentukan berdasarkan Rapat Anggota Tahunan (RAT).

o. Penetapan administrasi Dalam pembebanan. Biaya yang timbul dalam administrasi akan dibebankan kepada anggota/calon anggota yang mendapat pambiayaan. Diantanya untuk biaya materai dan lain-lain Koperasi Mitra Manindo dengan produk manindo grameen syariah tidak membebankan biaya administrasi kepada anggota di luar biaya administrasi real.

p. Denda dalam pembiayaan manindo grameen syariah. Dalam hal pembayaran apabila terjadi keterlambatan, maka anggota/anggota tidak di kenakan denda atau sanksi karna selama dalam 3 minggu berturut-turut anggota yang tidak mampu bayar akan ditalangi oleh anggota lain dengan sistem tanggung renteng dalam kumpulan.

q. Jaminan. Dalam produk manindo grameen syariah pihak koperasi tidak meminta jaminan dalam pembiaayaan tersebut dikarenakan tujuan dari pembiayaan ini adalah untuk membantu kaum perempuan dengan memberikan pembiayaan usaha tanpa agunan/jaminan dengan sistem kumpulan (kelompok).

Analisis yang dilakukan penulis terhadap pelaksanaan pembiayaan yang dilakukan oleh Koperasi Mitra Manindo kepada anggota/calon anggota koperasi adalah dengan menyediakan 
sejumlah uang yang akan digunakan oleh anggota/calon anggota sebagai modal atau tambahan modal usaha hal ini sesuai pengertian pembiayaan yang ada pada pasal 1 angka 12 Undang-Undang Nomor 10 tahun 1998 tentang perbankan yaitu: "pembiayaan berdasarkan prinsip syariah adalah penyedian uang atau tagihan yang dipersamakan dengan itu berdasarkan persetujuan atau kesepakatan antara bank dengan pihak lain yang mewajibkan pihak yang dibiayai untuk mengembalikan uang atau tagihan tersebut setelah jangka waktu tertentu dengan imbalan atau bagi hasil."

Menurut analisis penulis Pembiayaan Manindo Grameen Syariah yang ada di Koperasi Mitra Manindo Cabang Panyabungan dalam praktek pelaksanaannya telah sesuai dengan konsep grameen bank yaitu filosofi grameen bank dimana Pembiayaan ini ditujukan untuk mengentaskan kemiskinan lewat kaum perempuan dengan memberdayakan perempuan dalam bidang usaha yang produktif agar dapat membantu perekonomian keluarga secara mandiri dengan memberikan pelatihan serta tambahan modal usaha bagi kaum perempuan untuk lebih mandiri dalam hal ekonomi.

Selain itu, karakteristik program grameen syariah juga di terapkan di Koperasi Mitra Manindo Cabang Panyabungan dimana pembiayaan/ pinjaman diberikan tanpa agunan/jaminan, diprioritaskan bagi perempuan miskin yang memiliki usaha serta memenuhi uji kelayakan. Tata cara pembiayaan Manindo Grameen Syariah juga mengacu pada grameen bank dimana anggota koperasi mengajukan usulan pembiayaan, mengikuti Latihan wajib kumpul (LWK) atau lebih dikenal dengan istilah pertemuan kumpulan, pembiayaan diberikan secara individu/perorangan, angsuran di bayarkan setiap minggu dengan jangka waktu 25 minggu sampai dengan 50 minggu sesuai dengan jumlah pembiayaan yang telah diberikan oleh pihak koperasi ditambah $2 \%$ nisbah dari total pinjaman. Namun, ada kekurangan yang terlihat dari pengamatan penulis bahwa kurangnya pengawasan dari pihak koperasi setelah pembiayaan diberikan membuat sebagian anggota/calon anggota koperasi menggunakan pembiayaan bukan pada esensi /tujuan dari pembiaayaan itu sendiri melainkan menyimpang dari apa yang telah di tetapkan dalam akad perjanjian pembiaayaan tersebut dimana dalam produk manindo grameen syariah yang seharusnya pembiaayaan produktif untuk modal usaha malah sebaliknya dijadikan sebagai pembiayaan konsumtif oleh beberapa anggota/calon anggota Koperasi.

Kelebihan dari Pembiayaan murabahah adalah menggunakan metode pembayaran angsuran dengan kepastian jumlah angsuran yang harus dibayar oleh anggota setiap bulan. Anggota tidak akan dipusingkan dengan masalah naiknya angsuran apabila terjadi kenaikan suku bunga. Karena besarnya nilai angsurannya adalah tetap, sampai masa angsurannya selesai. Hal itu dikarenakan harga jual dan nisbah keuntungan yang telah disepakati dan ditetapkan diawal ketika anggota/calon anggota menandatangani akad pada pembiayaan tersebut.

Pembiayaan Murabahah pada Produk Manindo Grameen Syariah merupakan upaya yang dilakukan Koperasi Mitra Manindo dalam rangka membantu anggota/calon anggota koperasi untuk memperoleh kemudahan dalam menjalankan dan mengembangkan usaha serta dapat membantu pihak anggota untuk meningkatkan jumlah hasil serta mutu hasil produksi.

Secara teori Murabahah merupakan konsep jual beli yang sama sekali tidak ada hubungannya dengan pembiayaan. Namun, bentuk jual beli ini kemudian digunakan oleh lembaga keuangan syariah dengan menambah konsep pembiayaan. Akan tetapi, syarat dan 
rukun harus benar-benar diperhatikan agar transaksi tersebut diterima secara syari'ah. ${ }^{20}$ Pada prinsipnya transaksi murabahah harus memenuhi persyaratan yang dijadikan sebagai rukun murabahah itu sendiri.

Pembiayaan Murabahah yang ada di Koperasi Mitra Manindo Cabang Panyabungan belum 100\% sempurna dalam menerapkan kaidah-kaidah yang berlaku dalam akad murabahah, akad yang berlaku lebih dekat kepada konsep wakalah, misalnya dalam pembelian barang yang seharusnya pihak koperasi yang seharusnya menyediakan barang yang dibutuhkan oleh anggota, kemudian anggota membayar atas barang tersebut dengan cara mengangsur. Namun disini koperasi hanya menyerahkan (menitipkan) sejumlah uang yang dirincikan anggota/calon anggota koperasi untuk membeli barang keperluan usaha akan tetapi tanpa menggunakan akad wakalah tetapi menganggap sudah mewakalahkan hal tersebut kepada anggota/calon anggota koperasi yang membutuhkan pembiayaan. Tentu cara ini belum memenuhi rukun murabahah yaitu objek murabahah (mabi'). Pihak koperasi yang bertindak sebagai penjual barang kepada anggota tidak menunjukan barang sebagai objek jual beli murabahah melainkan memberikan sejumlah uang kepada anggota/calon anggota koperasi untuk membeli barang yang di butuhkan untuk kegiatan usaha ataupun modal usaha.

\section{Simpulan}

Pembiayaan murabahah Koperasi Mitra Manindo Cabang Panyabungan tidak menyediakan barang sebagai objek murabahah melainkan menyediakan uang dan tidak menggunakan akad wakalah. Koperasi mengganti akad mudharabah menjadi akad murabahah tetapi masih dengan skema mudharabah, adanya bagi hasil (margin) 2\% perbulan, berupa persentase dikalikan modal yang diajukan oleh nasabah/anggota koperasi, bukan dari harga pokok suatu barang yang real ditambah keuntungan, tidak adanya negosiasi mengenai bagi hasil untuk anggota baru kecuali sudah pernah melakukan pembiayaan murabahah di Koperasi Mitra Manindo dengan berbagai pertimbangan, di sini pihak nasabah/anggota koperasi mau tidak mau harus menerima dan menyetujui margin yang telah ditentukan tersebut.

Praktek pembiayaan murabahah di Koperasi Mitra Manindo Cabang Panyabungan belum sesuai dengan prinsip murabahah, Fatwa DSN No. 04/DSN-MUI/VI/2000 Tentang Murabahah juga menjelaskan bahwa, murabahah adalah jual beli barang kepada nasabah dengan harga jual senilai harga beli plus keuntungan, seharusnya koperasi dalam pelaksanaan pembiayaan akad murabahah diperuntukan untuk jual beli barang keperluan usaha produktif, bukan menyerahkan sejumlah uang yang bisa saja nasabah /anggota koperasi menggunakannya untuk biaya konsumtif dan dalam prakteknya pada kasus pembelian jenis barang tidak sesuai dengan akad yang telah disepakati, maka jual beli tersebut tidak sesuai dengan hukum Islam, karena mengandung unsur tadlis (penipuan). Koperasi yang bertindak sebagai penjual barang kepada nasabah tidak memiliki barang sebagai objek jual beli murabahah, terlepas dari ketentuan syara' yang telah melarang secara tegas (kecuali jual beli salam dan istisna). Jual beli salah satunya adalah tersedianya barang yang menjadi objek akad, akan tetapi dalam salah satu rukun jual beli tidak tersedia barang, maka transaksinya tidak sah karena salah satu rukun murabahah dalam tersedia barang tidak ada. Penetapan dalam penentuan keuntungan, telah ditentukan diawal akad berupa persentase $2 \%$ di kalikan modal, dengan demikian akan mengarah kepada riba. Sedangkan syarat yang harus dipenuhi supaya

${ }^{20}$ Fajrul Ilmi, "Implementasi Asas Kesetaraan Dalam Akad Pembiayaan Murabahah Pada Kpr-Btn Ib Di Btn Syariah Cabang Banjarmasin,” Shar-E : Jurnal Kajian Ekonomi Hukum Syariah 6, no. 2 (2020): 53-68.

Jurnal Baabu Al-ilmiVolume 6 No. 1 AprilTahun 2021 | 24 
menjadi sah tidak terjadi rusak pada akad murabahah di antaranya kontrak harus bebas dari riba.

\section{Daftar Pustaka}

Ahmed Chowdhury, Tanbir, and Sehel Somani. "Performance Evaluation and Impact of Grameen Bank on Social Development and Women Empowerment in Bangladesh." International Journal of Social and Administrative Sciences 5, no. 1 (2020): 54-73.

Alfiah, Esti. "Murabahah Contract With Delaying of Handover Object For Financing Mulia's Program (Case Studies at Pegadaian Syariah of Bengkulu)." Jurnal BAABU ALILMI: Ekonomi dan Perbankan Syariah 3, no. 1 (2019).

Baidhowi. "Rekonstruksi Akad Murabahah (Studi Akad Murabahah Di BMT SM NU Pekalongan)." YUDISIA: Jurnal Pemikiran Hukum dan Hukum Islam 8, no. 2 (2017): 221-239.

Elwardah, Khairiah. "Penyelesaian Pembiayaan Bermasalah Dalam Produk Pembiayaan Murabahah (Studi Pada Pt. Bprs Muamalat Harkat Sukaraja)." Jurnal BAABU ALILMI: Ekonomi dan Perbankan Syariah 4, no. 1 (2019): 75.

Fajrul Ilmi. "Implementasi Asas Kesetaraan Dalam Akad Pembiayaan Murabahah Pada KprBtn Ib Di Btn Syariah Cabang Banjarmasin." Shar-E: Jurnal Kajian Ekonomi Hukum Syariah 6, no. 2 (2020): 53-68.

Karim, Adiwarman. Bank Islam: Analisis Fiqih Dan Keuangan. Jakarta: Raja Grafindo, 2006.

Manindo, "Legalitas Kelembagaan”, Standar Operasional dan Prosedur Mitra Manindo Pola Syariah, 2019.

Mubarok, Ahmad Fauzan. "Tinjauan Hukum Islam Terhadap Program Pengentasan Kemiskinan Oleh Grameen Bank.” ISTI'DAL; Jurnal Studi Hukum Islam 4, no. 2 (2017): 105-119. https://ejournal.unisnu.ac.id/JSHI/article/view/775/1040.

Nasution, Lokot Zein. “Analisis Manajemen Risiko Pembiayaan Mikro Syariah Berbasis Karakteristik Masyarakat (Studi Pada Koperasi Mitra Manindo, Kabupaten Mandailing Natal, Sumatera Utara)." Jurnal Islaic Circle 1, no. 1 (2020): 1-26. https://doi.org/10.1016/j.tmaid.2020.101607\%0Ahttps://doi.org/10.1016/j.ijsu.2020.0 2.034\%0Ahttps://onlinelibrary.wiley.com/doi/abs/10.1111/cjag.12228\%0Ahttps://doi .org/10.1016/j.ssci.2020.104773\%0Ahttps://doi.org/10.1016/j.jinf.2020.04.011\%0Ah ttps://doi.o.

Nugrahani, Farida. Metode Penelitian Kualitatif. JAkarta: Library Stiba, 2014.

Sopiah, Anni. "Analisis Peranan Koperasi Mitra Manindo Siabu Dalam Meningkatkan Pendapatan Anggota Koperasi (Studi Kasus Di Desa Simaninggir).” Institut Agama ISlam Negeri (IAIN) Padangsidempuan, 2019.

Yunus, Muhammad, and Alan Jolis. Bank Kaum Miskin. Serpong: Marjin Kiri, 2013. 